University of Wollongong

Research Online

Faculty of Engineering and Information

Faculty of Engineering and Information

Sciences - Papers: Part A

Sciences

$1-1-2015$

Effective utilization of excess energy in standalone hybrid renewable energy systems for improving comfort ability and reducing cost of energy: A review and analysis

M Ismail Ismail

University of Malaysia, mi300@uow.edu.au

Mahmoud Moghavvemi

University of Malaya

T Mahlia

Universiti Tenaga Nasional,Selangor, Malaysia

Kashem M. Muttaqi

University of Wollongong, kashem@uow.edu.au

S Moghavvemi

University of Malaya

Follow this and additional works at: https://ro.uow.edu.au/eispapers

Part of the Engineering Commons, and the Science and Technology Studies Commons

Research Online is the open access institutional repository for the University of Wollongong. For further information contact the UOW Library: research-pubs@uow.edu.au 


\title{
Effective utilization of excess energy in standalone hybrid renewable energy systems for improving comfort ability and reducing cost of energy: A review and analysis
}

\begin{abstract}
One of the features that characterize renewable energy sources is their variability and intermittency. Intermittency covers both the predictable and unpredictable variations of their power outputs and uncertainty in the power availability. To overcome the drawback of intermittency, special design considerations should be taken into account. These additional design considerations increases the overall cost of the renewable energy systems. Adding storage system and/or backup source to the renewable sources is one of the measures used to guarantee the continuity of power supply to the loads, and therefore improve the reliability of the renewable energy systems. The operation of renewable energy systems results in the creation of surplus energy, which is the energy generated by renewable energy systems, but is not consumed by the loads in standalone power systems. Effective utilization of this excess energy has the potential to decrease the cost of energy (COE) production by these hybrid renewable energy systems. In this paper, a review of the literature will be carried out in order to provide further insight into the approaches suggested in the literature on how to deal with the utilization of excess energy. Furthermore, various possible configurations of hybrid systems will be analyzed in detail for the effective utilization of the excess energy produced by hybrid systems. This is done in order to evaluate the effectiveness of utilization of excess energy by various means, especially for improving the living space comfort ability and decreasing the COE. Case studies will be carried out to demonstrate the proposed configurations for the effective utilization of the excess energy, and the results will be presented.
\end{abstract}

\section{Keywords}

effective, cost, reducing, ability, comfort, improving, systems, renewable, analysis, hybrid, review, standalone, energy, excess, utilization

\section{Disciplines}

Engineering | Science and Technology Studies

\section{Publication Details}

M. Ismail, M. Moghavvemi, T. Mahlia, K. Muttaqi \& S. Moghavvemi, "Effective utilization of excess energy in standalone hybrid renewable energy systems for improving comfort ability and reducing cost of energy: A review and analysis," Renewable and Sustainable Energy Reviews, vol. 42, pp. 726-734, 2015. 


\title{
Effective utilization of excess energy in standalone hybrid renewable energy systems for improving comfort ability and reducing cost of energy: A review and analysis
}

\author{
M.S. Ismail ${ }^{\mathrm{a}, \mathrm{b}, *}$, M. Moghavvemi ${ }^{\mathrm{b}, \mathrm{c}, \mathrm{d}}$, T.M.I. Mahlia ${ }^{\mathrm{e}, \mathrm{f}}, \mathrm{K}$.M. Muttaqi ${ }^{\mathrm{g}}$, S. Moghavvemi $^{\text {h }}$ \\ a Electrical Engineering Department, Palestine Technical University-Kadoorie, Tulkarm, Palestine \\ ${ }^{\mathrm{b}}$ Center of Research in Applied Electronics (CRAE), University of Malaya, 50603 Kuala Lumpur, Malaysia \\ ${ }^{\mathrm{c}}$ Department of Electrical Engineering, University of Malaya, 50603 Kuala Lumpur, Malaysia \\ ${ }^{\mathrm{d}}$ University of Science and Culture, Tehran, Iran \\ e Department of Mechanical Engineering, Universiti Tenaga Nasional, 43000 Kajang, Selangor, Malaysia \\ ${ }^{\mathrm{f}}$ Department of Mechanical Engineering, Syiah Kuala University, Banda Aceh 23111, Indonesia \\ ${ }^{g}$ School of Electrical, Computer and Telecommunications Engineering, University of Wollongong, Wollongong, NSW, Australia \\ ${ }^{\mathrm{h}}$ Department of Operation and Management Information System, Faculty of Business and Accountancy University of Malaya, Kuala Lumpur, Malaysia
}

\section{A R T I C L E I N F O}

\section{Article history:}

Received 9 March 2014

Received in revised form

11 August 2014

Accepted 19 October 2014

Available online 10 November 2014

\section{Keywords:}

Dump load

Excess energy

Hybrid system

Renewable energy

\begin{abstract}
A B S T R A C T
One of the features that characterize renewable energy sources is their variability and intermittency. Intermittency covers both the predictable and unpredictable variations of their power outputs and uncertainty in the power availability. To overcome the drawback of intermittency, special design considerations should be taken into account. These additional design considerations increases the overall cost of the renewable energy systems. Adding storage system and/or backup source to the renewable sources is one of the measures used to guarantee the continuity of power supply to the loads, and therefore improve the reliability of the renewable energy systems. The operation of renewable energy systems results in the creation of surplus energy, which is the energy generated by renewable energy systems, but is not consumed by the loads in standalone power systems. Effective utilization of this excess energy has the potential to decrease the cost of energy (COE) production by these hybrid renewable energy systems. In this paper, a review of the literature will be carried out in order to provide further insight into the approaches suggested in the literature on how to deal with the utilization of excess energy. Furthermore, various possible configurations of hybrid systems will be analyzed in detail for the effective utilization of the excess energy produced by hybrid systems. This is done in order to evaluate the effectiveness of utilization of excess energy by various means, especially for improving the living space comfort ability and decreasing the COE. Case studies will be carried out to demonstrate the proposed configurations for the effective utilization of the excess energy, and the results will be presented.
\end{abstract}

(c) 2014 Elsevier Ltd. All rights reserved.

\section{Contents}

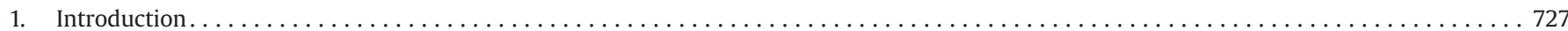

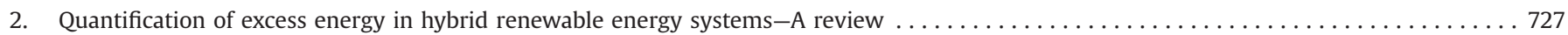

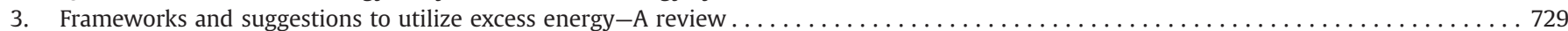

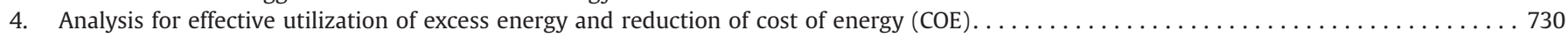

5. Utilizing excess energy to improve the comfort with no or minimal cost-A case study for heating and cooling . . . . . . . . . .

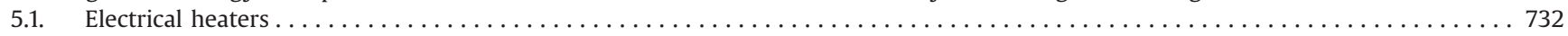

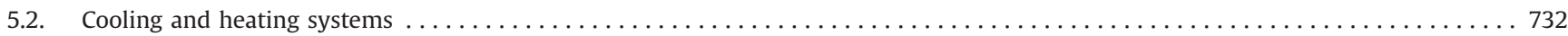

\footnotetext{
* Corresponding author. Tel.: +970 599566319.

E-mail addresses: m.ismail@ptuk.edu.ps, mahmoud_kafa@yahoo.com, mahmoud@um.edu.my (M.S. Ismail).
} 


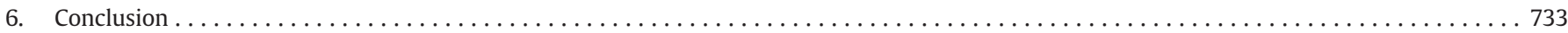

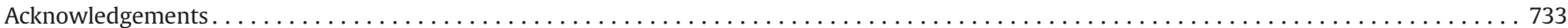

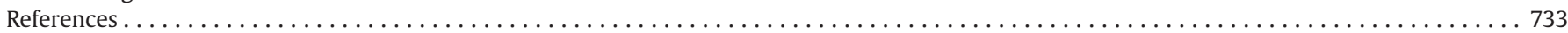

\section{Introduction}

Great efforts are made to develop new and renewable energy technologies along with energy storage systems and encourage their entry to the market of electric industry. These technologies can be operated as standalone sources, as part of hybrid systems, or as distributed generation connected to a microgrid or a distribution grid. These sources include photovoltaic systems, wind energy systems, diesel engines, fuel cells, microturbines, and different other renewable sources and storage systems.

These efforts are seeing a marked increase recently due to the fact that different types of fossil fuel that conventional sources of energy depend on are going to be depleted. When this is taken into consideration, along with the fact that high levels of global warming gases are emitted as a result of combustion of these fossil fuels, this encourages different institutions and authorities worldwide to invest in local generation from renewable energy sources [1-3]. This involves finding substitutes, or at least reducing the dependency on fossil fuels. Furthermore, an overview of the literature on rural electrification proves shows that renewable energy sources are one of the most effective solutions to provide power to rural areas that are located far from the electrical power grid. Delivering high quality and reliable electricity for different applications in these remote areas were also proven to be feasible [4-6].

Renewable energy sources are non-depleted, non-polluting, and location dependent. Recently, utilization of renewable sources has become more attractive, cost effective, and significant. However, because renewable sources are variable and intermittent, a need for a storage system and/or backup source arises to ensure continuity in supplying the load [7-9].

Hybrid energy systems are systems that combine two or more energy conversion sources (electricity/heat generation and/or storage devices), and when combined, will overcome any inherent limitations [10-14]. If one of these energy sources is renewable, this hybrid system can be treated as a hybrid renewable energy system.

When hybrid systems operated effectively, they increase the overall efficiency of the system and become a more reliable energy supply. Moreover, hybrid renewable energy systems can significantly reduce the cost of generation and the environmental impacts. Utilization of hybrid systems that combines renewable sources with backup sources and energy storage reduces the limitations of renewable sources, and open up markets for investment that might not otherwise exist. Hybrid systems take the best features of differing, but complementary resources in its construction $[15,16]$.

For systems with more than one energy sources used to supply a load, a criterion to manage the power flow between these sources should be specified. This management strategy should define the priorities to dispatch the energy between the different sources. For the system considered in this study, the priority is to maximize the utilization of energy generated by the renewable sources (e.g. PV panels) and the energy stored in the battery bank. In case of inability of these sources to cover the load demand, one or more non-renewable (e.g. microturbine or diesel generator) or renewable but schedulable (biomass) standby resources can be used to counteract demand-generation mismatch in these standalone hybrid systems. For the case where the generated energy exceeds the load requirement and the battery, if available in the hybrid system, is not able to store anymore as it is full, an excess energy that should either be dumped or utilized for ancillary service (or other purpose) to maintain a power balance in the system. Fig. 1 shows the flowchart guiding the management strategy to achieve energy balancing for this situation.

Different configurations can be followed in designing standalone hybrid systems to effectively utilize the available renewable energy sources and to serve the customer loads. Any combination of renewable sources is possible, but it may require an optional backup source and/or storage system. To select the most appropriate configuration for a specific site, a feasibility study considering the meteorological data of this site and based on life cycle cost analysis should be done.

One of the drawbacks of the renewable energy systems is their high capital cost compared to conventional ones. Using hybrid systems that combine more than one energy source and the size optimization of each of the components constructing these systems are some of the measures that can be taken to reduce their capital costs. Effective utilization of any excess energy that hasn't been consumed by the load or used to charge the battery in standalone hybrid systems can be considered as one of the approaches used to decrease the cost of energy (COE) production for these hybrid systems.

Actually, this excess energy, if not dumped, may damage the battery due to the fact that it might result in an overcharge. It may also cause over voltages in the standalone hybrid systems that, in turn, may adversely affect the equipment connected to the system. The traditional way to overcome this excess energy is through using dump loads to consume it. Resistors are usually used for this purpose, and a controller usually diverts the extra power away from the battery banks and directs it into the designated (dedicated) dump load when the desired voltage of the battery bank is reached. Values of these resistors should be selected in order to allow enough current to pass through. The diversion control circuit may be included in the charger regulator circuit, in the inverter circuit, or in the rectifier circuit, as most of the manufacturers of these power electronic interfaced renewable energy systems usually include these diversion control circuits within their products [17].

Instead of dumping the excess power through a dump load, other alternatives to deal with this excess power have been suggested by many researchers, and can be found in the literature. To the best of the authors' knowledge, a detailed analysis to evaluate the effectiveness of utilization of the excess energy has not been previously carried out. In this paper, a review of the literature will be carried out in order to assess approaches being suggested to deal with the excess energy produced but not used either to supply the load or charge the batteries. Furthermore, hybrid system configurations will be analyzed in detail in order to evaluate the effectiveness of utilization of excess energy by various means, especially for improving the living space comfort ability without any additional cost.

\section{Quantification of excess energy in hybrid renewable energy systems-A review}

In this section, a review of various studies carried out in different locations around the world will be presented. The purpose of this review is to indicate the percentage of the excess 


\begin{tabular}{|c|c|c|c|}
\hline \multicolumn{2}{|c|}{ Nomenclature } & $m_{w}$ & water mass (kg) \\
\hline $\mathrm{COE}$ & cost of energy & $P_{\text {RE-out }}$ & output power from renewable sources $(\mathrm{kW})$ \\
\hline$C_{p w}$ & water specific heat $\left(C_{p w}=4.18 \mathrm{~kJ} / \mathrm{kg} /{ }^{\circ} \mathrm{C}\right)$ & $T_{\text {fin }}$ & final temperature $\left({ }^{\circ} \mathrm{C}\right)$ \\
\hline$E_{h}$ & heat energy $(\mathrm{kW} \mathrm{h})$ & $T_{\text {ini }}$ & initial temperature $\left({ }^{\circ} \mathrm{C}\right)$ \\
\hline
\end{tabular}

energy generated but not used by different configurations of hybrid systems analyzed in these reviewed studies.

For a study conducted by Demiroren and Yilmaz [18] to supply the electrical requirement of the Island Gokceada, Turkey, it was found that the optimal scenario is the one constructed from wind turbines. For this optimized scenario, it was found that the excess energy constructs about $64.2 \%$ of the total electrical production.
For another study carried out for the case of remote location in India, Sen and Bhattacharyya [19] found that 25\% of the total energy is generated by a hybrid system, which is constructed using a PV system, wind turbines, a hydropower system, and bio-diesel generators, goes to dump loads.

For a study directed to Waterloo in Ontario, Hafez and Bhattacharya [20] analyzed four different cases to supply a certain load.

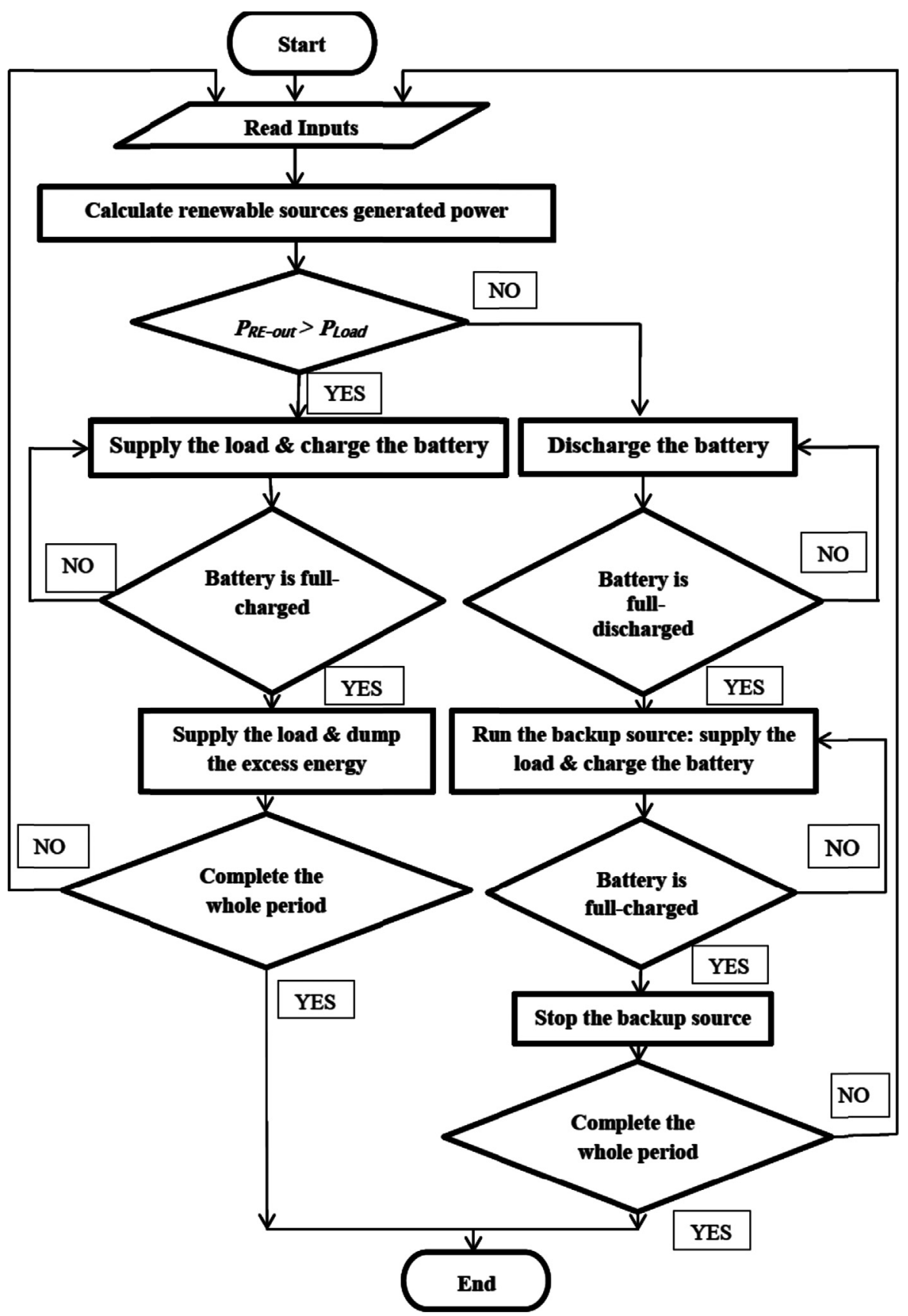

Fig. 1. Flowchart for the energy management strategy. 
They found that $70 \%$ of the total energy production goes to dump loads for a fully renewable scenario where the sources are wind turbine, solar panels, and a small-scale hydro station. For the diesel only case, this percentage is $51.1 \%$, whereas, it is $16.9 \%$ for the mixed case. For a standalone system constructed from PV panels and wind turbines without any storage system, Ipsakis et al. [21] found that it was $56.4 \%$ of the total time, and excess energy is available. This evaluation was conducted through simulated experiments for the region of Xanthi, Greece. For another study directed for a remote location in Palestine, Daud and Ismail [22] found that 33\% of the total generated energy has not been used. The hybrid system analyzed in this study was constructed from PV panels, wind turbine, battery system, and diesel generator.

For a separate study conducted at Qurayat (Northern Province of the Saudi Arabia), Shaahid et al. [23] concluded that the percentage of the excess energy increases as the PV penetration in a PV/battery/ diesel generator hybrid system increases. For a $65 \% \mathrm{PV}$ penetration, the excess energy is 35\%, whereas it is about $47 \%$ for a $69 \%$ PV penetration. In a separate study that was also conducted for Saudi Arabia, Rehman and Al-Hadhrami [24] found that the excess energy from a PV/battery/diesel generator hybrid system was $0.67 \%$ of the total generated energy, where the PV penetration was $21 \%$. They stated that this percentage would increase to $9.94 \%$ if the PV penetration would increase to $42 \%$. An analysis of a case study for a rural remote area in India illustrated that the amount of excess energy was $0.48 \%$, and this occurred for a $20 \% \mathrm{PV}$ penetration in a PV/diesel generator/battery system [25]. In a study conducted to optimize and design a hybrid system constructed from PV panels, battery bank, and diesel generator in order to supply a remote house in Langkawi Island-Malaysia, Ismail et al. [26] found that the excess energy that couldn't be used by the system amounts to $14 \%$ of the total generated energy. Moghavvemi et al. [27] found that the excess energy that was generated but not used was about $16.3 \%$ of the total generated energy. The system supplied power to a remote controlled commercial large scale FM transmitter using a PV/ battery/diesel generator hybrid system. In a separate study conducted for Malaysia, Khatib et al. [28] found that about 2.3\% of the total generated energy was excess energy. In their analysis of the hybrid system that was constructed from PV panels, diesel generator and battery, they allowed a certain value for the loss of load probability (LLP) rather than zero.

In their study, Ismail et al. [29] found that $8 \%$ of the total generated energy went to dump loads. This study involved supplying power to a remote small community in Palestine using a PV/ battery hybrid system, with a microturbine as a backup source.

Razak et al. [30] evaluated the effect of the load profile and the amount of the load energy on the amount of the excess energy. They have concluded that the load profile shape has an obvious effect of the amount of the excess energy.

Table 1 summarizes the percentage of the excess energy for various hybrid system configurations analyzed in various studies conducted previously.

According to the previously reviewed studies in this section, it can be concluded that the amount of excess energy generated by any hybrid renewable energy system depends on the types of the energy sources used in the hybrid system, the sizes of these components, the availability and the profiles of the meteorological quantities, and the load profile variations with respect to variations in meteorological quantities.

\section{Frameworks and suggestions to utilize excess energy-A review}

In this section, a review of many studies carried out in various locations around the world will be presented. Part of these studies
Table 1

Percentage of excess energy for various hybrid system configurations analyzed in various studies carried out previously.

\begin{tabular}{lll}
\hline Reference & Type of hybrid system & $\begin{array}{l}\text { Percentage of excess } \\
\text { energy }\end{array}$ \\
\hline$[18]$ & PV/wind/battery & 64.2 \\
{$[19]$} & PV/wind/hydropower/bio-diesel & 25 \\
& generators & 70 \\
{$[20]$} & PV/wind/hydropower & 51.1 \\
{$[20]$} & Diesel generator & 16.9 \\
{$[20]$} & PV/wind/hydropower/diesel generator & $56.4^{*}$ \\
{$[21]$} & PV/wind & 33 \\
{$[22]$} & PV/wind/battery/diesel generator & $35^{* *}$ \\
{$[23]$} & PV/battery/diesel generator & $9.49^{* * *}$ \\
{$[24]$} & PV/battery/diesel generator & $0.48^{* * * *}$ \\
{$[25]$} & PV/battery/diesel generator & 14 \\
{$[26]$} & PV/battery/diesel generator & 16.3 \\
{$[27]$} & PV/battery/diesel generator & 2.3 \\
{$[28]$} & PV/battery/diesel generator & 8 \\
{$[29]$} & PV/battery/microturbine &
\end{tabular}

* Percentage of the total time at which an excess energy is available.

*** At the case where the PV penetration equals to 65\%.

**** At the case where the PV penetration equals to $42 \%$.

****** At the case where the PV penetration equals to $20 \%$

suggests dumping this excess energy by using dump loads, whereas the rest suggest utilizing this excess energy by various means.

Mousavi [31] suggested that the dump load be used to consume the excess energy generated by the wind/tidal/microturbine/battery hybrid system. In their study, the dump load used consists of three phase resistors. Demiroren and Yilmaz [18] suggested allowing the excess energy to be exported to the grid. In a study conducted on the performance analysis of hybrid renewable energy systems, Jebaselvi and Paramasivam [32] suggested using dump loads in order to get rid of the excess generated energy. Ziogou et al. [33] suggested utilizing the excess energy to produce hydrogen through a proton membrane electrolyszer. They also recommended storing this hydrogen in pressurized cylinders to be used in a proton exchange membrane fuel cell for the case of power shortage. In a study directed to design and analyze a hybrid energy system with wind and solar power, Kabalci [34] suggested dump loads to be used to consume excess power. In another study conducted to design isolated hybrid renewable systems, Sreeraj et al. [35] suggested dumping the excess energy generated by their proposed system in dump loads. Ranjeva and Kulkarni [36] proposed selling excess energy generated by the hybrid systems back to the grid. Sebastian and Quesada [37] recommended using dump load to consume any excess energy generated by their analyzed hybrid systems dominated by wind turbine as a renewable source. The dump load used in [37] consists of eight threephase resistors connected in series, and gate turn-off thyristor switches are used to connect and disconnect these resistances. In the energy management strategy stated in the study conducted to analyze the economic and the environmental aspects of standalone energy systems, Fux et al. [38] recommended diverting any excess energy to a dump load. In a study conducted to analyze the feed-in-tariffs and their effect on promotion of storage systems, Krajacic et al. [39] suggested delivering any excess energy to the grid, or use it to pump water uphill or dump it. In a study conducted to model, simulate, and control flat PV solar collectors with the ability to store thermal energy for heating and cooling purposes, Mosallat et al. [40] proposed storing any electrical or thermal excess energy to be used for cooling or to be used during the cool season if a long-term storage has been applied. Actually, this is also important to prevent damage to the solar collectors. A thermal storage tank with a built in heat exchanger is proposed for this purpose. The heat extracted from the flat collectors via 
Glycol flowing through pipes installed in the collectors is transferred via the heat exchanger to the water in the tank. Sen and Bhattacharyya [19] suggested feeding any excess energy generated by their analyzed off-grid renewable systems to dump loads. Inverson et al. [41] and Agbossou et al. [42] suggested using hydrogen storage technology in order to utilize the excess energy produced during the surplus periods. This excess energy was used to power an electrolyzer to produce and store hydrogen. This stored hydrogen was used as a fuel for a fuel cell to supply loads in deficient periods. In two additional studies, Vosen and Keller [43] and Bernal-Agustín, and Dufo-López [44] suggested using, in addition to the battery bank as a storage system, a hydrogen storage system in case of excess energy. In a study to design of hybrid renewable energy systems, Hafez and Bhattacharya [20] proposed supplying the excess energy to the dump load. They used HOMER to perform the optimization, and they suggested using a heat load as a dump load, and supplying it using the excess energy. A comparison between the case where the excess energy was just fed to a dump load and the case where the excess energy was fed to the heat load was not included in this study. In a study conducted to optimize a renewable standalone system to supply power to Dongfushan Island-China, Zhao et al. [45] suggested including a seawater desalination system to work as a controllable load. As they stated, this would relieve water supply challenges in the island and serve as a balance for any excess energy generated by the renewable energy sources. Kaldellis and Zafirakis [46] suggested rejecting any excess energy generated by their proposed PV/wind turbine hybrid system to water heating as a dump load. As an alternative, they suggested using this excess energy to supply heat pumps for heating and cooling purposes. The power management strategy developed by Ipsakis et al. [21] stated that any excess energy generated by a standalone renewable energy system should be used to generate hydrogen via water electrolysis to be used in a polymer electrolyte membrane fuel cell to generate electricity during power shortage. If the hydrogen tank is filled, a battery bank shall be charged using the surplus in generated energy. A dump load should be used to prevent overcharging of the battery when its state of charge reaches $100 \%$. Li et al. [47] described in their study a virtual power station that suggested aggregating small-scale PV systems to be presented to the wider electrical system as a lumped point. For managing the intermittency of the photovoltaic system, dumping of excess energy into dump loads (resistor banks or heaters) or using battery banks for excess energy storage has been suggested. Two scenarios were studied to deal with the system dumping; in the first one, it was suggested that the excess energy for each individual source be dumped, and then aggregate the rest, while in the second scenario; however, in the second study, it was suggested that the individual energies be aggregated, and the excess energy dumped. It was found that using the second scenario resulted in more energy aggregation and more earning in the income. In the study presented in [23], the authors suggested supplying the excess energy to dump loads. In a review study regarding the grid-tie generation systems without storage systems, Yanine and Sauma [48] have stated that the overall efficiency of the grid connected system is better than the standalone system efficiency, as the grid behaves as unlimited storage system, and due to this, it is not required that it dumps excess energy to dump excess energy. They have recommended not dumping excess energy, especially for remote locations, where the need for energy is vital. So, they suggest utilizing the excess energy by different means: space heating or cooling, water heating, water pumping, water desalination, and others. Gupta et al. [25], in their study, suggested diverting any excess energy to a dump load, which was assumed to be electric water heaters. In their study to analyze the technical and the economic aspects of integrating renewable sources with energy storage systems, Connolly et al. [49] suggested using the excess energy to replace the thermal production. Malla and Bhende [50] analyzed the factors that affect the voltage of PV/ wind standalone systems. They suggested feeding the excess energy of the proposed hybrid system to the aqua electrolyzer. Since electrolyzers are still expensive, and in order to specify their sizes, the authors recommended considering only $60 \%$ of the maximum available excess energy. Khan and Iqbal [51] suggested using the excess energy in space heating or water pumping. This increased the overall efficiency of their analyzed standalone hybrid energy systems. In a study conducted to model and simulate hybrid renewable energy systems, Tsao et al. [52] suggested supplying the excess energy to electrolyze water in order to produce hydrogen for use as fuel to the fuel cell as part of their hybrid system. Patsios et al. [53] suggested using electrolyzer to dump excess energy. Additionally, they suggested using dump resistive loads to dump any excess energy not being used by the electrolyzer. In [28], it was suggested that any excess energy that may exist after charging the battery be injected to the main grid.

According to the types of components constructing the hybrid system, the excess energy may be electrical, or it might be in other forms. Some of the means proposed utilizing the excess energy directly when it is available; space heating or cooling are example of these means. The others utilize the excess energy when it is available to be stored in one of various storage means. Storing this excess energy in storage batteries allow it to be used later to supply electrical loads, obtaining hot water, and storing it in storage tanks to be use later for various domestic applications, obtaining hydrogen, and storing it to be used later in fuel cells to generate electricity, and pumping water to an elevated storage tank to be used later to run a hydro generator to generate electricity are some of the examples of storage means.

The hybrid renewable energy system may include one or more of these means. This depends on the type of the components of the hybrid systems and the amount of the excess energy. In the case of more than one means of utilizing excess energy, a controller that receives its control signals from the various components should be included to manage the excess energy flow within the hybrid system.

A block diagram of a hybrid system that includes various means to utilize the excess energy is shown in Fig. 2. This block diagram also includes various types of energy sources, number of storage technologies, and various types of loads.

\section{Analysis for effective utilization of excess energy and reduction of cost of energy (COE)}

The purpose of this study is to analyze the effect of utilizing excess energy on the COE. For this purpose, the authors used the earlier studies for both the Palestinian case [22], and the Malaysian case [26]. Each of these two studies analyzes hybrid renewable energy systems in detail to supply domestic loads. In each of these two studies, it was recommended that the excess energy generated through the operation of these analyzed hybrid systems be dumped.

The COE production is the cost of generating one unit of energy $(\mathrm{kW} \mathrm{h})$. To calculate its value, all types of costs have been taken into account. The initial costs of various components constructing the hybrid system, the installation costs, the maintenance costs, the operating costs, and the replacement costs have been considered in the analysis. The value of money, the economic figures (the inflation rate and the interest rate) and salvage value for components to be replaced have been also taken into account in this analysis. More details regarding this can be found in both [22] and [26]. 


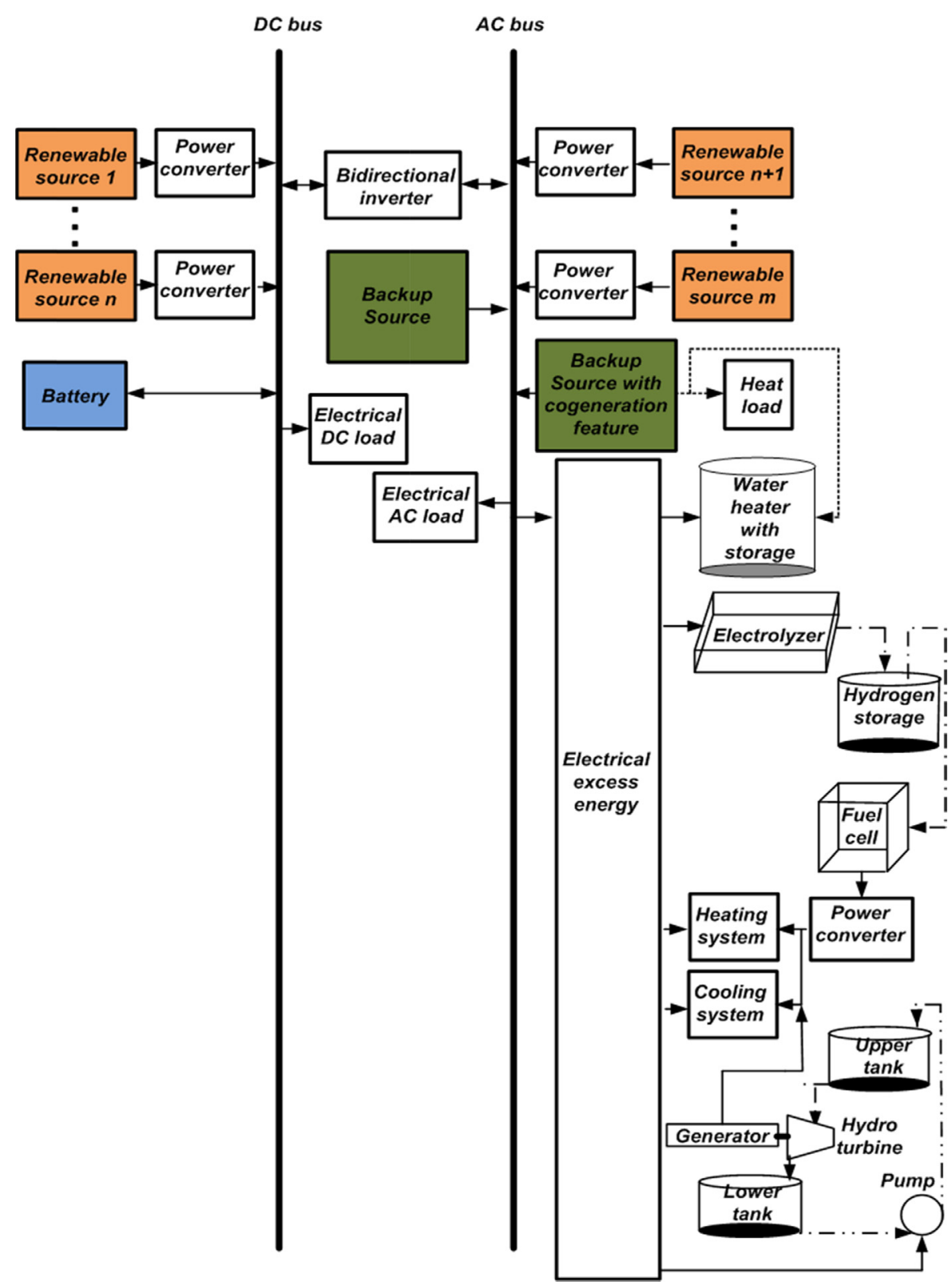

Fig. 2. Block diagram of the hybrid system with various possibilities to utilize excess energy.

So, in the present work, these studies have been extended to include COE production as well. The purpose of this study is to analyze the effect of excess energy utilization on the overall COE production.

The COE production from the PV/wind/diesel hybrid system analyzed in [22] is $0.281 \$ / \mathrm{kW} \mathrm{h}$. Utilizing the excess energy generated by this hybrid system decreases the COE production to $0.182 \$ / \mathrm{kWh}$ (i.e. the percentage of reduction is $35.2 \%$ ). In the same study, the COE from the PV/diesel hybrid system is 0.332 $\$ / \mathrm{kW} \mathrm{h}$, whereas utilizing the excess energy from this hybrid system decreases the COE to $0.252 \$ / \mathrm{kWh}$ (i.e. percentage of reduction is $24.1 \%)$. Utilizing the excess energy from the standalone hybrid system analyzed in the same study decreases from $0.743 \$ / \mathrm{kW}$ h to $0.372 \$ / \mathrm{kW}$ h (i.e. percentage of reduction is $49.9 \%$ ). It is obvious that the amount of reduction in COE depends on the type and configuration of hybrid systems.

The COE from the PV/diesel hybrid system presented in [26] is $0.239 \$ / \mathrm{kW}$ h. The reduction in COE due to the utilization of the excess energy amounts to $16.4 \%$. For the PV standalone hybrid system analyzed in the same study, the reduction in the COE due to the excess energy utilization is $39 \%$.

For the hybrid system analyzed in [27], the percentage of the excess energy is $16.3 \%$. The COE production as a result of this PV/diesel hybrid system is $0.259 \$ / \mathrm{kW} \mathrm{h}$. The COE, taking into account the excess energy utilization decreases to $0.21 \$ / \mathrm{kW}$ h. This means that a reduction in the COE amounts to $18.9 \%$. For the PV standalone hybrid system scenario analyzed in the same study, the reduction is $36.6 \%$.

The COE of the PV/microturbine hybrid system presented in [29] is $0.284 \$ / \mathrm{kW}$ h. This is for the case where the cogeneration feature of the microturbine has not been considered. For the same case, and taking into account the utilization of the excess energy, the COE decreases to $0.258 \$ / \mathrm{kW}$ h (i.e. the percentage of the reduction is $9.2 \%$ ). Considering the cogeneration feature of the microturbine, the reduction in the COE is $1.9 \%$. For the PV standalone hybrid system scenario, the reduction percentage in the COE due to the excess energy utilization is $60.4 \%$, where the COE before the utilization of the excess energy is $0.57 \$ / \mathrm{kW} \mathrm{h}$, whereas the COE after utilization is $0.226 \$ / \mathrm{kW}$ h. 
Table 2

Percentage of reduction in COE due to utilization of the excess energy for selected studies carried out for both Palestinian and Malaysian cases.

\begin{tabular}{|c|c|c|c|}
\hline Reference & Type of hybrid system & Location & Percentage of reduction in $\mathrm{COE}(\%)$ \\
\hline [22] & $\mathrm{PV} /$ wind/battery/diesel generator & Palestine & 35.2 \\
\hline [22] & PV/battery/diesel generator & Palestine & 24.1 \\
\hline [22] & PV/wind/battery & Palestine & 49.9 \\
\hline [26] & PV/battery/diesel generator & Malaysia & 16.4 \\
\hline [26] & PV/battery & Malaysia & 39 \\
\hline [27] & PV/battery/diesel generator & Malaysia & 18.9 \\
\hline [27] & PV/battery & Malaysia & 36.6 \\
\hline [29] & PV/battery/microturbine (without cogeneration utilization) & Palestine & 9.2 \\
\hline [29] & PV/battery/microturbine (with cogeneration utilization) & Palestine & 1.9 \\
\hline [29] & PV/battery (with cogeneration utilization) & Palestine & 60.4 \\
\hline
\end{tabular}

Table 2 includes a summary for the percentage of reduction in COE due to the excess energy utilization for selected studies carried out for both Palestinian and Malaysian cases.

\section{Utilizing excess energy to improve the comfort with no or minimal cost-A case study for heating and cooling}

In the following subsections, a case study is presented, which demonstrates the utilization of the excess energy at minimal cost.

\subsection{Electrical heaters}

Supplying the electrical excess energy to the electrical heaters provided with storage tanks for hot water is one of ways to utilize the excess energy at almost no cost. Homes, as well as many industrial and manufacturing applications, are usually provided with these types of storage heaters. The only requirement to utilize the excess energy to supply such loads is the need to include a diversion control circuit in one of the power electronics circuits included in the renewable system. As stated earlier, most of the manufacturers of these power electronics circuits usually include these diversion control circuits in their designs.

A simple calculation indicates that the energy required for water heating is quite high. So, an alternative of supplying these heaters from the main supply is to use any amount of excess energy to supply these heaters. The amount of heat energy $\left(E_{h}\right)$ required to raise the temperature of a certain amount of water $\left(m_{w}\right)$ in $(\mathrm{kg})$ from an initial temperature $\left(T_{i n i}\right)$ to a final temperature $\left(T_{f i n}\right)$ can be calculated using the following formula:

$E_{h}=m_{w} \times C_{p w} \times\left(T_{f i n}-T_{i n i}\right)$

where $C_{p w}$ is the watersspecific heat $\left(C_{p w}=4.18 \mathrm{~kJ} / \mathrm{kg} /{ }^{\circ} \mathrm{C}\right)$.

Taking into account the Palestinian case, the temperature of domestic water in winter may take values between $5{ }^{\circ} \mathrm{C}$ to $10{ }^{\circ} \mathrm{C}$, whereas in the summer, this temperature may take values between $15{ }^{\circ} \mathrm{C}$ to $20^{\circ} \mathrm{C}$. Assuming an amount of $4000 \mathrm{l}$ being the family consumption of monthly heated water for domestic applications, the energy required to raise the temperature of this amount of water to $40-45{ }^{\circ} \mathrm{C}$ (the comfort temperature for bath, shower, or other cleaning and washing applications) can be calculated using Eq. (1). Using this equation and taking into account the center of each of the mentioned temperature ranges, the amount of energy required for this purpose in one of the winter months equals $162.5 \mathrm{~kW} \mathrm{~h}$ (each $3600 \mathrm{~kJ}$ is equivalent to $1 \mathrm{kWh}$ ). In summer, the monthly required energy equals $116 \mathrm{~kW} \mathrm{~h}$
Table 3

Monthly excess energy generated by the wind/PV/diesel generator hybrid system.

\begin{tabular}{rll} 
Month & $\begin{array}{l}\text { Excess energy by the system } \\
\text { suggested in [22] }(\mathrm{kW} \mathrm{h}) \\
\text { (Palestinian case) }\end{array}$ & $\begin{array}{l}\text { Excess energy by the system } \\
\text { suggested in }[26](\mathrm{kW} \mathrm{h}) \\
\text { (Malaysian case) }\end{array}$ \\
\hline 1 & 846.00 & 435.21 \\
2 & 695.55 & 338.13 \\
3 & 1112.35 & 427.19 \\
4 & 1345.63 & 369.37 \\
5 & 707.79 & 395.49 \\
6 & 1020.96 & 450.70 \\
7 & 1196.27 & 246.18 \\
8 & 944.76 & 398.15 \\
9 & 616.06 & 368.43 \\
10 & 500.77 & 440.59 \\
11 & 557.47 & 331.05 \\
12 & 512.95 & 318.81 \\
\hline
\end{tabular}

\subsection{Cooling and heating systems}

Another example is the space heating and cooling systems. These systems are usually required in both the winter and the summer. For a typical home with an area within the range from 100 to $150 \mathrm{~m}^{2}$, the capacity of the air conditioner suitable for this home is about $2 \mathrm{t}$ (which can be 2 split units each with $1 \mathrm{t}$ ). The electrical rating for this air conditioner capacity is about $2.7 \mathrm{~kW}$ (this value depends on the energy efficiency value and the coefficient of performance of the air conditioner, the mode of operation, the climate conditions and others). Assuming 6 h daily operation of this air conditioner, the monthly energy consumption of this system will be about $486 \mathrm{~kW} \mathrm{~h}$. Using programmable thermostat can be effective with such systems to utilize any excess energy whenever it is available. With these programmable thermostats, many features can be obtained. Multiple setback settings, adjustment for daylight saving periods, considering the schedules of occupancy of the space, and considering the periods of possible excess energy are part of these features.

For the wind/PV/diesel generator hybrid system analyzed in [22], which directed to supply a family house in Palestine, Table 1 displays the monthly excess energy that is generated by the hybrid system but not consumed by the load. For the same house, and considering the electric heater and the air conditioner described before, the monthly total energy consumed is $648.5 \mathrm{~kW} \mathrm{~h}$ in winter, and $602 \mathrm{~kW}$ h in summer. It can be observed that for most months, there is still an excess energy after supplying these loads. For only 3 months (October to December), there is still a need to use a small amount of energy from the energy directed to the main loads.

From the previous analysis, the homes that utilize excess energy to run the electric heater and the air conditioner can also have hot water for many domestic applications, as well as a 
comfort environment without any additional cost. In other words, considering these mentioned loads as part of the total load supplied by the energy generated by the hybrid system, the effective COE has been decreased by $35.2 \%$.

For the PV/diesel generator hybrid system analyzed and its results presented in [26], Table 3 displays the monthly excess energy generated as a result of running this system. This study was conducted for the case of Malaysia. Malaysia is located in the equatorial region and its climate is categorized as equatorial, being hot and humid throughout the year. Assuming the same amount of water to be heated (i.e. 40001 monthly) with a temperature that can be in the range of $20-25^{\circ} \mathrm{C}$, the monthly energy required to raise the temperature of this amount of water to $40-45{ }^{\circ} \mathrm{C}$ is $92.9 \mathrm{~kW}$ h (the center of temperature ranges is used in calculations). Also taking into account the air conditioning system described above, the monthly total energy consumed by both the electrical heater and the air conditioner is $578.9 \mathrm{~kW} \mathrm{~h}$. The amounts of the excess energy listed in Table 1 should cover a high percentage of the energy required to supply both the loads, which is about $65 \%$ of the total required energy. In other words, this will decrease the effective COE by $16.4 \%$.

\section{Conclusion}

In this paper, a review of the literature dealing with the methods to utilize the excess energy and analysis of effective utilization of excess energy has been carried out. The review shows that considerable amounts of excess energy can be left unutilized as a result of running hybrid renewable energy systems. Some studies suggest dumping the excess energy through dumped loads, while others propose utilizing this excess energy. Various methods have been proposed for this purpose. For grid connected hybrid systems, any excess energy can be injected to the grid. In standalone operation, using excess energy to produce hydrogen using electrolyzers and then storing this hydrogen in hydrogen tanks to be used by the fuel cells when there is a shortage in power supply was one of the proposals. However, this is actually a costly suggestion. Water heating, water pumping, and space heating and cooling are other alternatives in utilizing the excess energy. For some special cases, it is proposed that the excess energy be used for water desalination. Studies also revealed that cost of the energy (COE) can be reduced if excess energy is utilized. In this paper, scenario-based case studies were carried out to relate the cost of energy production to the utilization of the excess energy for various hybrid system configurations. An analysis for specific systems in both the Palestinian case and the Malaysian case showed that a considerable reduction in the COE production was observed when excess energy was utilized. In the analysis, it is found that hot water for domestic applications and space heating or cooling by air conditioning can be achieved with little to minimal cost.

\section{Acknowledgements}

The authors would like to acknowledge the Ministry of Higher Education of Malaysia and The University of Malaya, Kuala Lumpur, Malaysia for the financial support under UM.C/HIR/MOHE/ENG/21 (D000021-16001).

\section{References}

[1] Perera ATD, Attalage RA, KKCK Perera, Dassanayake VPC. Designing standalone hybrid energy systems minimizing initial investment, life cycle cost and pollutant emission. Energy 2013;54:220-30.
[2] Tazvinga H, Xia X, Zhang J. Minimum cost solution of photovoltaic-dieselbattery hybrid power systems for remote consumers. Sol Energy 2013;96:292-9.

[3] Ahmed T, Muttaqi K, Agalgaonkar A. Climate change impacts on electricity demand in the State of New South Wales, Australia. Appl Energy 2012;98:376-83.

[4] Ma T, Yang H, Lu L. Performance evaluation of a stand-alone photovoltaic system on an isolated island in Hong Kong. Appl Energy 2013;112:663-72.

[5] Mendis N, Muttaqi KM, Sayeef S, Perera S. Standalone operation of wind turbine-based variable speed generators with maximum power extraction capability. IEEE Trans Energy Convers 2012;27:822-34.

[6] Ismail MS, Moghavvemi M, Mahlia TMI. Energy trends in Palestinian territories of West Bank and Gaza Strip: possibilities for reducing the reliance on external energy sources. Renewable Sustainable Energy Rev 2013;28:117-29.

[7] Hoicka CE, Rowlands IH. Solar and wind resource complementarity: advancing options for renewable electricity integration in Ontario, Canada. Renewable Energy 2011;36:97-107.

[8] Mendis N, Muttaqi K. An integrated control approach for standalone operation of a hybridised wind turbine generating system with maximum power extraction capability. Int J Electr Power Energy Syst 2013:49:339-48.

[9] Chauhan A, Saini RP. A review on integrated renewable energy system based power generation for stand-alone applications: configurations, storage options, sizing methodologies and control. Renewable Sustainable Energy Rev 2014;38:99-120.

[10] Bajpai P, Dash V. Hybrid renewable energy systems for power generation in stand-alone applications: a review. Renewable Sustainable Energy Rev 2012;16:2926-39.

[11] Mendis N, Muttaqi KM, Perera S. Management of battery-supercapacitor hybrid energy storage and synchronous condenser for isolated operation of pmsg based variable-speed wind turbine generating systems. IEEE Trans. Smart Grid 2014;5:944-53.

[12] Ismail MS, Moghavvemi M, Mahlia TMI. Current utilization of microturbines as a part of a hybrid system in distributed generation technology. Renewable Sustainable Energy Rev 2013;21:142-52.

[13] Ismail MS, Moghavvemi M, Mahlia TMI. Genetic algorithm based optimization on modeling and design of hybrid renewable energy systems. Energy Convers Manage 2014;85:120-30.

[14] Dufo-López R, Bernal-Agustín JL, Contreras J. Optimization of control strategies for stand-alone renewable energy systems with hydrogen storage. Renewable Energy 2007;32:1102-26.

[15] Kaldellis JK, Zafirakis D, Kavadias K. Minimum cost solution of windphotovoltaic based stand-alone power systems for remote consumers. Energy Policy 2012;42:105-17.

[16] Kanase-Patil AB, Saini RP, Sharma MP. Integrated renewable energy systems for off grid rural electrification of remote area. Renewable Energy 2010;35: 1342-9.

[17] Wholesale Solar Website; 2014. 〈http://www.wholesalesolar.com/products. folder/controller-folder/xantrexC35.html > accessed 1st March 2014.

[18] Demiroren A, Yilmaz U. Analysis of change in electric energy cost with using renewable energy sources in Gökceada, Turkey: an island example. Renewable Sustainable Energy Rev. 2010;14:323-33.

[19] Sen R, Bhattacharyya SC. Off-grid electricity generation with renewable energy technologies in India: an application of HOMER. Renewable Energy 2014;62: 388-98.

[20] Hafez O, Bhattacharya K. Optimal planning and design of a renewable energy based supply system for microgrids. Renewable Energy 2012;45:7-15.

[21] Ipsakis D, Voutetakis S, Seferlis P, Stergiopoulos F, Elmasides C. Power management strategies for a stand-alone power system using renewable energy sources and hydrogen storage. Int J Hydrogen Energy 2009;34:7081-95.

[22] Daud A, Ismail MS. Design of isolated hybrid systems minimizing costs and pollutant emissions. Renewable Energy 2012;44:215-24.

[23] Shaahid SM, Al-Hadhrami LM, Rahman MK. Review of economic assessment of hybrid photovoltaic-diesel-battery power systems for residential loads for different provinces of Saudi Arabia. Renewable Sustainable Energy Rev 2014;31:174-81.

[24] Rehman S, Al-Hadhrami LM. Study of a solar PV-diesel-battery hybrid power system for a remotely located population near Rafha, Saudi Arabia. Energy 2010;35:4986-95.

[25] Gupta A, Saini RP, Sharma MP. Steady-state modelling of hybrid energy system for off grid electrification of cluster of villages. Renewable Energy 2010;35: 520-35.

[26] Ismail MS, Moghavvemi M, Mahlia TMI. Techno-economic analysis of an optimized photovoltaic and diesel generator hybrid power system for remote houses in a tropical climate. Energy Convers Manage 2013;69:163-73.

[27] Moghavvemi M, Ismail MS, Murali B, Yang SS, Attaran A, Moghavvemi S. Development and optimization of a PV/diesel hybrid supply system for remote controlled commercial large scale FM transmitters. Energy Convers Manage 2013;75:542-51.

[28] Khatib T, Mohamed A, Sopian K, Mahmoud M. Optimal sizing of building integrated hybrid PV/diesel generator system for zero load rejection for Malaysia. Energy Build 2011;43:3430-5.

[29] Ismail MS, Moghavvemi M, Mahlia TMI. Design of an optimized photovoltaic and microturbine hybrid power system for a remote small community: case study of Palestine. Energy Convers Manage 2013;75:271-81.

[30] Razak JA, Sopian K, Ali Y. Optimization of renewable energy hybrid system by minimizing excess capacity. Int J Energy 2007;1:75-81. 
[31] Mousavi SMG. An autonomous hybrid energy system of wind/tidal/microturbine/battery storage. Electr Power Energy Syst 2012:43:1144-54.

[32] Jebaselvi GDA, Paramasivam S. Analysis on renewable energy systems. Renewable Sustainable Energy Rev 2013;28:625-34.

[33] Ziogou C, Ipsakis D, Elmasides C, Stergiopoulos F, Papadopoulou S, Seferlis P, et al. Automation infrastructure and operation control strategy in a standalone power system based on renewable energy sources. J Power Sources 2011;196:9488-99.

[34] Kabalci E. Design and analysis of a hybrid renewable energy plant with solar and wind power. Energy Convers Manage. 2013;72:51-9.

[35] Sreeraj ES, Chatterjee K, Bandyopadhyay S. Design of isolated renewable hybrid power systems. Sol Energy. 2010;84:1124-36.

[36] Ranjevaa M, Kulkarnia AK. Design optimization of a hybrid, small, decentralized power plant for remote/rural areas. Energy Procedia 2012;20:258-70.

[37] Sebastián R, Quesada J. Distributed control system for frequency control in a isolated wind system. Renewable Energy 2006;31:285-305.

[38] Fux SF, Benz MJ, Guzzella L. Economic and environmental aspects of the component sizing for a stand-alone building energy system: a case study. Renewable Energy 2013;55:438-47.

[39] Krajačić G, Duić N, Tsikalakis A, Zoulias M, Caralis G, Panteri E, et al. Feed-in tariffs for promotion of energy storage technologies. Energy Policy 2011;39: $1410-25$.

[40] Mosallat F, Elmekkawy T, Friesen DL, Molinski T, Loney S, Bibeau EL. Modeling, simulation and control of flat panel solar collectors with thermal storage for heating and cooling applications. Procedia Comput Sci 2013;19:686-93.

[41] Iverson Z, Achuthan A, Marzocca P, Aidun D. Optimal design of hybrid renewable energy systems (HRES) using hydrogen storage technology for data center applications. Renewable Energy 2013;52:79-87.

[42] Agbossou K, Kolhe M, Hamelin J, Bose TK. Performance of a stand-alone renewable energy system based on energy storage as hydrogen. IEEE Trans Energy Convers 2004;19:633-40.
[43] Vosen SR, Keller JO. Hybrid energy storage systems for stand-alone electric power systems: optimization of system performance and cost through contro strategies. Int J Hydrogen Energy 1999;24:1139-56.

[44] Bernal-Agustín JL, Dufo-López R. Simulation and optimization of standalone hybrid renewable energy systems. Renewable Sustainable Energy Rev 2009;13:2111-8.

[45] Zhao B, Zhang X, Li P, Wang K, Xue M, Wang C. Optimal sizing, operating strategy and operational experience of a stand-alone microgrid on Dongfushan Island. Appl Energy 2014;113:1656-66.

[46] Kaldellis JK, Zafirakis D. Optimum sizing of stand-alone wind-photovoltaic hybrid systems for representative wind and solar potential cases of the Greek territory. J Wind Eng Ind Aerodyn. 2012;107-108:169-78.

[47] Li J, Guo Y, Platt G, Ward JK. Renewable energy aggregation with intelligent battery controller. Renewable Energy 2013;59:220-8.

[48] Yanine FF, Sauma EE. Review of grid-tie micro-generation systems without energy storage: towards a new approach to sustainable hybrid energy systems linked to energy efficiency. Renewable Sustainable Energy Rev 2013;26: $60-95$.

[49] Connolly D, Lund H, Mathiesen BV, Pican E, Leahy M. The technical and economic implications of integrating fluctuating renewable energy using energy storage. Renewable Energy 2012;43:47-60.

[50] Malla SG, Bhende CN. Voltage control of stand-alone wind and solar energy system. Int J Electr Power Energy Syst 2014;56:361-73.

[51] Khan MJ, Iqbal MT. Pre-feasibility study of stand-alone hybrid energy systems for applications in Newfoundland. Renewable Energy 2005;30:835-54.

[52] Tsao T-F, Chen P-H, Chen H-C. Dynamic modeling and simulation of hybrid power systems based on renewable energy. In: ICEET '09 international conference on energy and environment technology; 2009. p. 602-605.

[53] Patsios C, Antonakopoulos M, Chaniotis A, Kladas A. Control and analysis of a hybrid renewable energy-based power system. In: 2010 XIX international conference on electrical machines (ICEM); 2010. p. 1-6. 